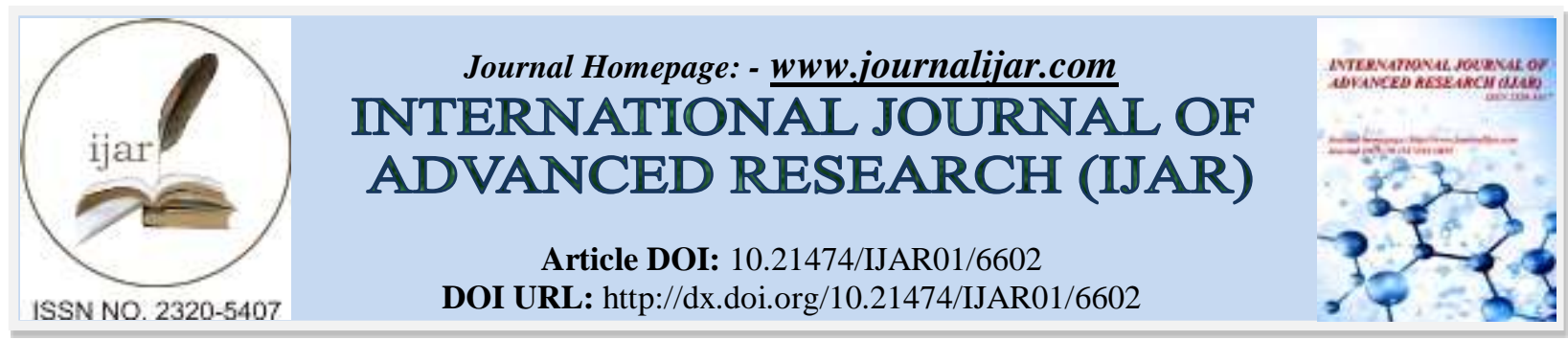

RESEARCH ARTICLE

\title{
THE IMPACT OF PERCEIVED ORGANIZATIONAL PERFORMANCE ON EMPLOYEES' INTENTIONS TO IMPLEMENT MANAGEMENT CONTROL TOOLS IN PUBLIC HIGHER EDUCATION INSTITUTIONS: A QUALITATIVE STUDY.
}

1. Dean of Business School - Al Jinan University.

2. Lecturer at the Lebanese University and Al Jinan University.

\section{Manuscript Info}

\section{Manuscript History}

Received: 21 December 2017

Final Accepted: 23 January 2018

Published: February 2018

\section{Key words:-}

Perceived Organizational

Performance, Employees' Attitude,

Public Higher Education

Organization, Management Control tools.

\begin{abstract}
The aim of this research is to investigate the factors that influence the Perceived Organizational Performance construct in the Lebanese Public higher education institutions. Our objectives are firstly, to simplify the process of implementing Management Control Tools in the Lebanese University for decision makers. Secondly, to enable them to take more oriented decision when implementing information systems. Thirdly, to enhance the decision making process in the Lebanese University (LU) by maximizing the use of management control tools that cannot be done without knowing what drives employees to use such tools. We adopted a mixed method methodology, qualitative and quantitative. The qualitative method that served as an exploratory study, used observation and semi-structured interviews techniques, while the quantitative method that was used to test the model, was based on an online survey technique. This article shows the result of the qualitative study, which enabled us to create an adapted relational model to be later tested using the Partial Least Square-Path Modeling (PLSPM).
\end{abstract}

Copy Right, IJAR, 2018,. All rights reserved.

\section{Introduction:-}

Researchers in Management have put tremendous efforts in trying to understand the factors that affect the organizational performance in private and public organizations. Some of them investigated external and internal factors while others created strategic management tools frameworks. The aim of this research is to investigate the factors that influence the Perceived Organizational Performance construct in the Lebanese University. The Lebanese University is the only public higher education institution in Lebanon. Its existence is a vital factor to the wellbeing of the Lebanese society.

In their report in 2008, the Organization for Economic Co-Operation and Development Organization (OECD) stated that higher education policies are increasingly gaining attention nationwide. Nowadays, governments recognize that Higher Education is a determinant factor in the context of a global economy that increasingly relies on knowledge to advance (OECD, 2008, p. 1). Higher Education Institutions are restructuring their systems. They are observing the labor market, adapting their curriculums and introducing new majors. These shifts entail a restructuring of the current higher education strategies. Universities need to adapt their missions, visions, and objectives in order to keep pace with current social, economic, and cultural requirements. 
The Arab world is facing unstable situation in the context of higher education. According to the UNDP report in 2014, the Arab states are influenced by the emigration of highly skilled academics and researchers. It is estimated that 10 to $15 \%$ of the Arab youth migrate, and that the migration rate is high among graduates of Higher Education Institutions in Arab countries. In Lebanon, the rate reaches 35\%, while in Morocco it reaches 17\%. (UNDP, 2014, p. 5). The report also indicates that reputed public universities have inadequate teaching methods, an extreme shortage of research policies, in addition to obsolete academic decisions. The situation in the private universities is different, it is characterized by being more successful, and result oriented. However, in his report, Nahas (2009) stated that the Lebanese higher education system is somewhat different from those of the Arab countries. He noted that the common approach to higher education in the MENA countries is characterized by the following:

1. Higher education provision is dominated by the public sector;

2. There is a major financing problem and

3. There is an increasing demand for enrollment in Higher Education Institutions

While in Lebanon, the situation is different. It is characterized by the following:

1. The private sector historically dominates the education sector: out of 41 Higher Education Institutions, only one is public, the Lebanese University (LU), and the majority of the student body is enrolled in private universities;

2. Financing of education in general and higher education in particular is exceptionally abundant;

3. No demographic increase is foreseeable: in 2025, the youth population is expected to decrease by $5 \%$.

4. The Lebanese University has the largest stake of students among private universities. Yet a quick comparison between public and private sector universities shows that the Lebanese University has a stable enrollment rate across the years while in private universities the enrollment rate is slightly increasing. The following two graphs (Figure 1) highlight this fact.

5.

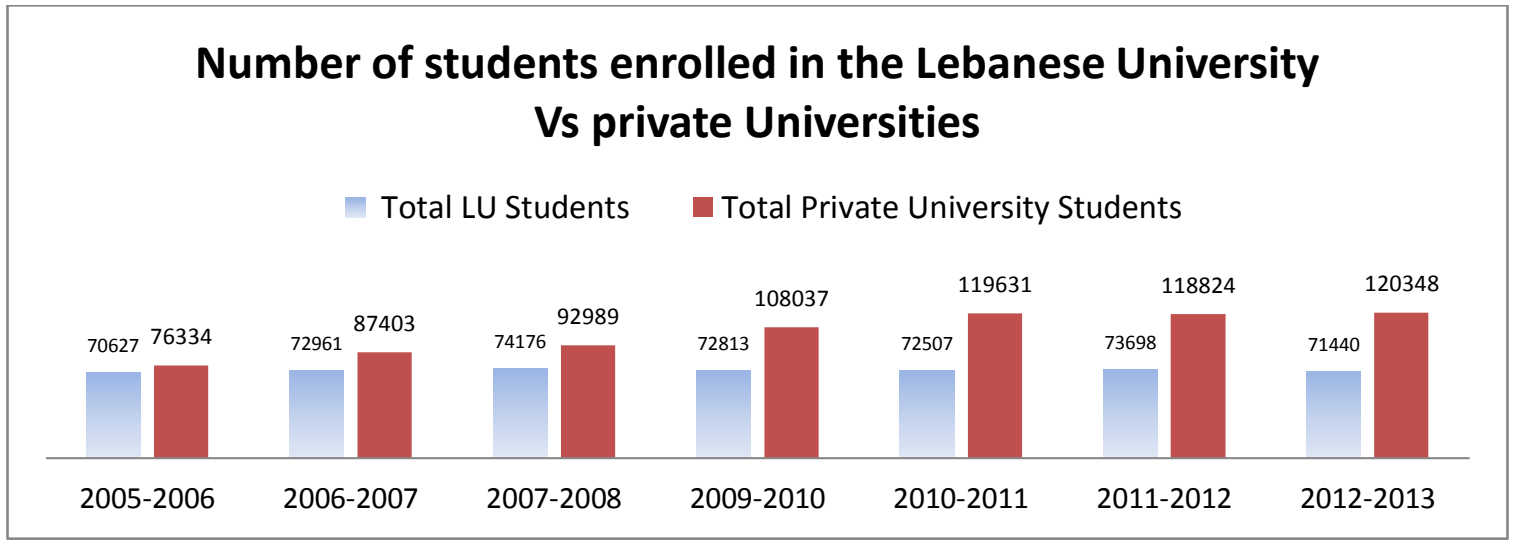

Figure 1:- Number of students enrolled in the Lebanese University Vs. Private Universities

This decrease in the Lebanese University stake of students to the benefit of private universities is due, to the fact that the Lebanese Government is unable to delineate a strategic vision for education in general and higher education in particular, resulting in the explosion of private higher education and diminishing means quality and presence for the only public institution (Nahas, 2009).

Moreover, Al-Amin et al. (1999) noted that the Lebanese University had been severely damaged by the Lebanese civil war on multiple levels e.g. Its mission and strategies; Its independence; Branching; Buildings and equipment; Programs and curricula and scientific research; The academic hierarchy; The administrative staff; The financial situation. 


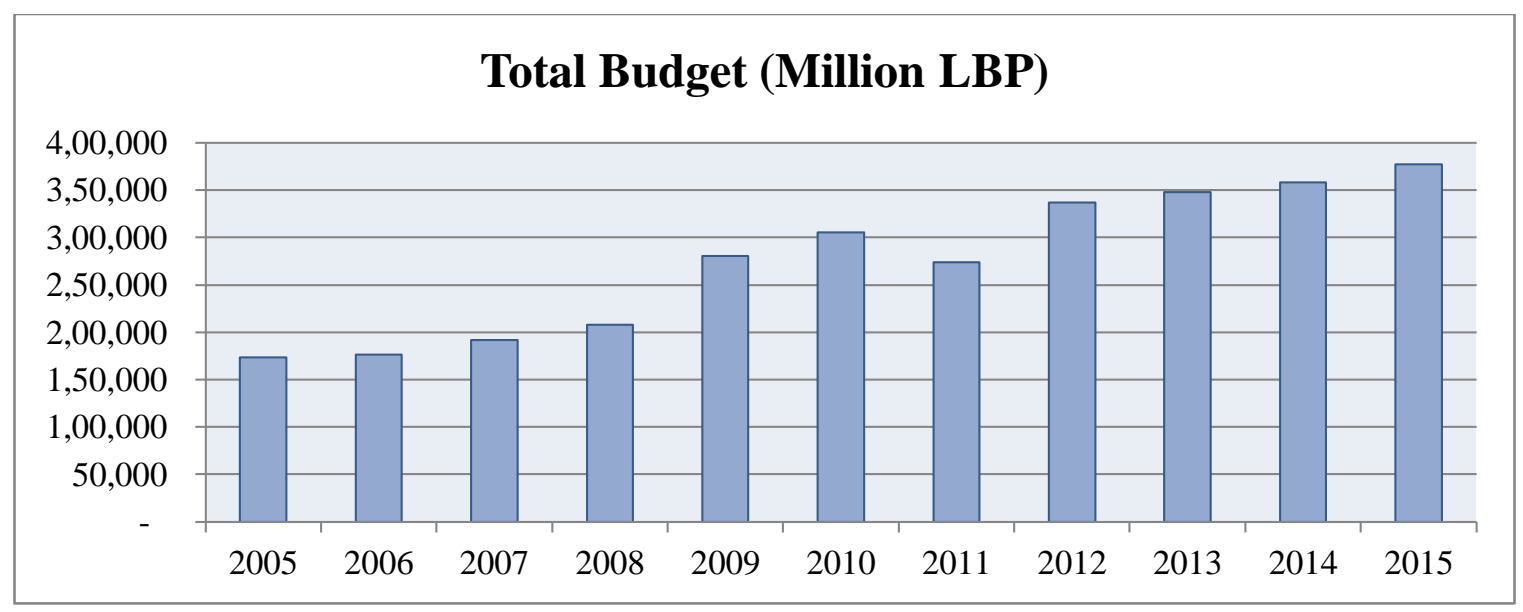

Figure 2:- Budget trend from 2005 until 2015 Source: Statistical Departmen in The Lebanese University

This quick overview of the history of higher education in Lebanon and the number of students enrolled in the Lebanese University and the financial situation is meant to highlight that the Lebanese University is facing two types of challenges. On one hand, private universities are attracting more students thus decreasing the stake of the Lebanese University. On the other hand, the government is not keeping pace with the numerous needs of the Lebanese University, in addition to licensing more Private Universities, thus, authorizing higher Education Institutions that are driven by financial purposes, rather than enhancing higher education norms. However, despite all these challenges, the Lebanese University remains one of the most important universities in Lebanon (Nahas, 2009).

Therefore, our problem statement is to investigate the factors that influences the Perceived Organizational Performance construct in the Lebanese University. The research objectives can be summarized as follow:

- To simplify the process of implementing management control tools in the Lebanese University.

- To help decision makers to take more oriented decisions when implementing information systems and management control tools, by knowing the antecedents of the Perceived Organizational performance construct.

- To enhance the decision making process in the Lebanese University by maximizing the use of management control tools that cannot be done without knowing what drives employees to use such tools.

\section{Literature review:-}

1) Using General and Social Systems theory to understand the $L U$ and its personnel as a system

General and Social Systems is the basic theory used in our study. It allows us to understand the Lebanese University as a system that receives inputs and generates outputs along with a close interaction with the environment surrounding it. The theory also explains the individual (an employee) as a system. The employee will receive inputs e.g. orders, salary and will eventually generate outputs (e.g. tasks, usage of new tools, acceptance of change etc.)

2) Using intention models to understand how a behavior is formed

The implementation of any management control tool depends basically on the attitude of managers and human resources toward the change (Ajzen I. , 1991; Ajzen \& Flood, 2009). Before they accept to make any change, they need to have a positive attitude toward using the new Management Control Tools and Information System practices. For these reasons, intention models are used as a second theoretical basis to predict employees' attitude toward the implementation of MCT and IS.

Nowadays, management science researchers are increasingly using intention models to predict different managerial topics, namely, entrepreneurial intentions for students, public employees' intentions to use information systems (Venkatesh \& Morris, 2000; Davis et al., 1992).

In the context of our study, we needed to use a third set of theories to understand what could possibly drive employees to use PMSs and IS. These theories are organizational performance antecedents. The driver to use these was a study done by Bartunek \& Franzak (1988) who stated that there are two levels of change in the organization whenever there are change initiatives. The first level is called "alpha" change and linked to improvements within 
previously accepted frameworks. The second level is "gamma" change and linked to discontinuous shifts in frameworks (Bartunek \& Franzak, 1988)

3) Using organizational performance theories to understand the drivers of organizational performance in the Lebanese University

Researchers found evidence of the relationship between enhancing organizational performance and acceptance of change by organizations' members (Alexander, 2000; Brewer \& Selden, 2000).

Thus, the objective of this literature review is to investigate the possible antecedents of organizational performance. In our case, we are investigating the effect of the various constructs on the Perceived Organizational Performance construct.

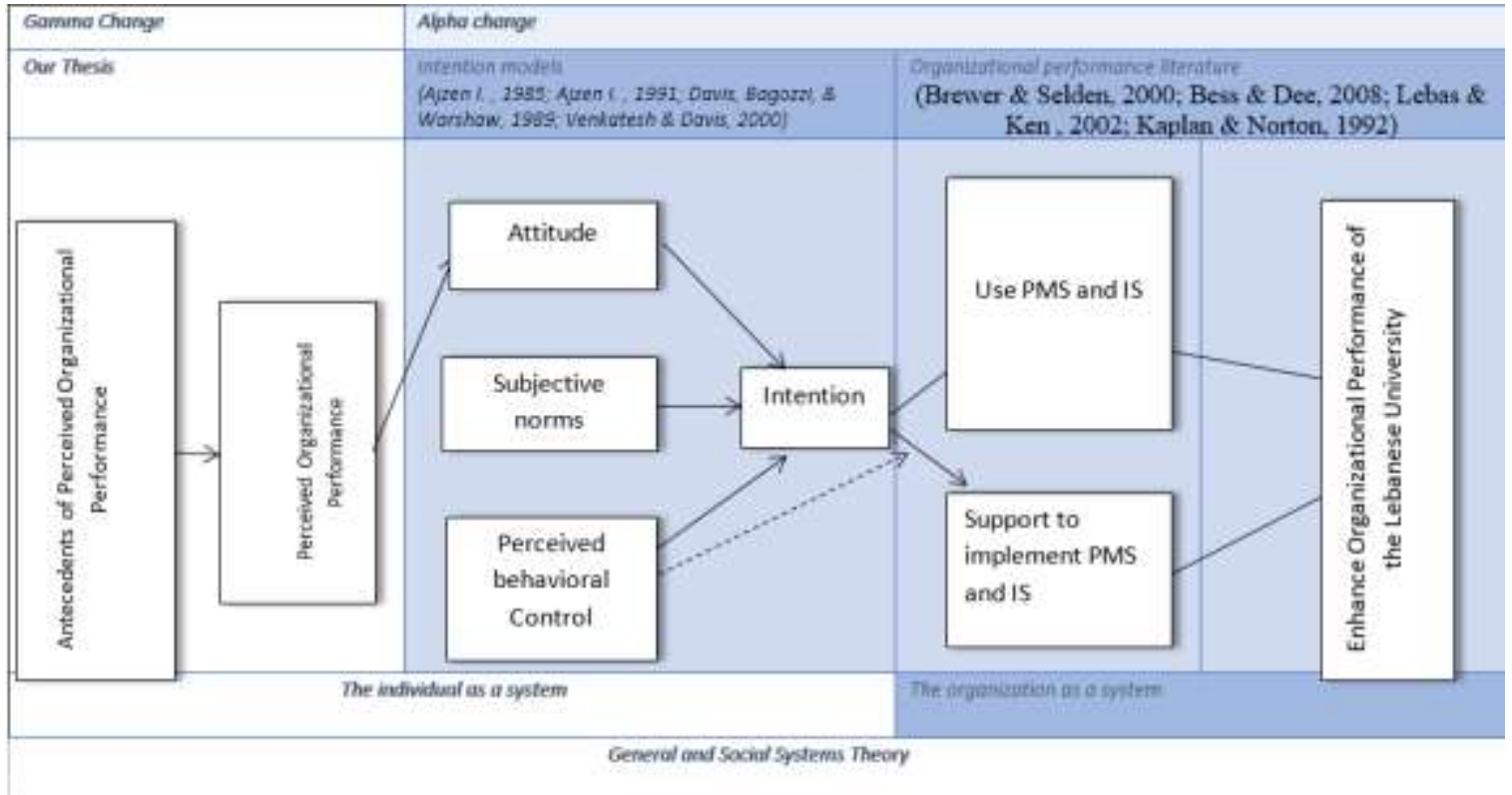

Figure 3:- Summary of the Theoretical Framework

\section{Methodology:-}

For this research we opted for a qualitative study consisting of observation in one of the Lebanese University faculties and semi structured interviews with key personnel in the Lebanese University.

\section{4) Observation}

An immersed observant is when he is called a participant observant. This case represents the highest degree of participation in the group's activity during which the researcher shares the same experience and has the same objectives as the group being observed. Following Adler \& Adler's (1987) suggestions, being emotionally and ideologically close to the group members, fosters not only an open attitude among the group members, but also, helps the researcher to reach higher levels of comprehension of the phenomenon being studied. Thus, the aim of observation becomes efficient in answering questions such as "how" and "why." The objective of observation in this case is exploratory, explanatory, or descriptive. As an active observer, we could get more involved in the institution's operations, we interact more closely with the institution's human resources, and we could access more information. Nevertheless, we can identify more accurately the themes to be used in the interview guide that will direct the semi-structured interview.

Consequently, our observations permitted us to take a broad view of the possible causes of the lack of perceived organizational performance. These conclusions stimulated an increased interest in the problems and further readings. The themes (issues) were extracted from observations in one of the Lebanese University faculties.

1. The mission vision and strategies of the faculty;

2. The communication channels between hierarchical positions; 
3. Decision making and communicating new decisions;

4. The evolution perspectives;

5. The administrative situation in the Lebanese university (Bureaucracy);

6. The technological situation LU (adoption of new technologies);

7. The financial situation;

8. Power perception and political influence.

\section{5) Semi-Structured Interviews}

The reason that triggered the use of semi-structured interviews is the ability of this exploratory tool to surface the hidden perceptions and attitudes towards many organizational aspects. Depending on the interview guide and the direction of the interviewer, semi-structured interviews would bring up some notions that observations alone or a survey alone would not be able to capture. Our observations surfaced many themes that need to be empirically tested. These themes are of a human nature and perceptions. As a result, semi-structured interviews are suitable to delve deeper into the mind and conscience of employees working at the Lebanese University. The scope of our research was to find the variables that influence the construct Perceived Organizational Performance. In order to preserve the privacy of the interview, we performed one to one interviews in the offices of the employees. Thus, making them feel at ease without any pressure of external factors (Fern, 1982).

Table (1) indicates the number of interviewee by positions, and the duration of each interview. In the hierarchical level section, there are three categories of interviewees.

Table 1:- Semi structured interview Sample

\begin{tabular}{|l|l|l|}
\hline Type of Interviewee & Number of interviews & Number of hours \\
\hline Administrative Head of Department (rank 3) & 19 & 29.5 \\
\hline Faculty Member & 5 & 8 \\
\hline Employee & 6 & 7 \\
\hline Total & $\mathbf{3 0}$ & $\mathbf{4 4 . 5}$ \\
\hline
\end{tabular}

a) Interview guide

The observation methodology enabled us to write our first interview guide (see Appendix A). Subsequently, we turned back to the literature in order to calibrate our questions and the main topics to be discussed during interviews. Based on the themes extracted from the observation phase, we created the first set of questions to guide the semistructured interviews. Then we compared our guide with other guides from the literature reviews. We found various interview guides in various types and fields of research see for example (Harb, 2011; Deem, Hillyard, \& Reed, 2007). We built on these interview guides to create our own. We, then, adjusted the first version of the interview guide and created the second version.

\section{b) Conducting interviews}

While conducting interviews, two principals were adhered to in order to conserve internal validity:

- Questions were practically the same in each interview according to the themes highlighted in the interview guide.

- In some cases, we rephrased and summarized the interviewee ideas. After having his consent on the summary, we then considered his response in the transcription for later analysis.

c) Difficulties encountered while conducting the semi-structured interviews

We came across many difficulties while conducting semi-structured interviews. Most of the interviewees expressed in various ways their unwillingness to disclose information that might reveal critical aspects of their jobs. Their reluctance to answer questions related to the financial situation, accountability and other issues that they considered as a "black box" drove us to ask more of the cuff questions. These questions were used as a second way to trigger more accurate and specific responses. Yet, some interviewee did not contribute sufficiently to the aims of the research because the interviewee showed resistance towards many of the questions. Some interviews were selforiented meaning that the interviewee kept speaking on personal achievements and departmental achievements. They presumed that by doing so they could avoid answering critical questions. Therefore, more oriented question was asked to adjust the path of the interview. 


\section{d) Content analysis of semi-structured interviews}

In order to analyze the data from the semi-structured interview we opted to choose content analysis method. The objective of this method, which is widely used in social science, is to trigger new questions that could lead us, to have a clearer understanding on the issue we are dealing with (Quivy \& Campendhout, 1995, p. 202). Content analysis was employed in order to calibrate the research and to extract new directions. In other words, this method will act as the research compass.

Content analysis is defined as "A set of communication analysis techniques aimed, through systematic and objective procedures of messages description, to obtain indicators allowing the inference of knowledge about the conditions of production / reception of these messages" (Evrard, Pras, \& Roux, 1997, p. 126)

In addition, content analysis aims at simplifying the presentation of the data extracted from the field, enabling a better management and a simple analysis of the results. Thietart (1999) noted that there are three methods to perform content analysis: thematic, syntactic, and lexical. We opted to use the thematic analysis, which indicates that we must observe the redundancy of themes during interviews and encompass them in meaningful themes.

Having done many observations in vivo of a Lebanese University faculty, we managed to have some themes that were predetermined and were gathered and regrouped according to their relativity. Afterward, when tackling the semi-structured interview transcriptions, we discovered some of the major themes that resulted from observation and which were in accordance with the results of the interviews. Nevertheless, and as expected, new themes also arose. As a result, the objectives of the research have been diverged in some points that were impossible to identify only by observing the events. Then, we opted to analyze interviews manually after transcribing them and typing up a soft copy of the speech. Subsequently, we read them as a whole one more time. Reading the transcription allowed us to remove any unwanted paragraphs. Then we began analyzing the text in details. Statements were divided into groups of similar meaning and subjects. This resulted in the creation of themes and sub-themes that were redundant in many sections and by many interviewees. The consolidation of the themes and sub-themes we grouped in the Matrix of qualitative data analysis (see Appendix B). Then the quantification of the redundancy of these themes were showed in Appendix C. The themes extracted from semi-structured interviews were grouped according to Perry J. (1997) and Steers R. (1977) frameworks. In Appendix (B), we counted the themes related to each Latent variable of the five constructs used in Perry J. (1997) and Steers R. (1977) frameworks (e.g. External Environment Characteristics, Work Environment Characteristics, Individual Characteristics, Job Characteristics, and Perceived Organizational Performance).

\section{Findings:-}

The themes extracted from semi-structured interviews were grouped according to Perry J. (1997) and Steers R. (1977) frameworks. In this section, we will present the results of the qualitative study and we will link them to the elaboration of the survey's items. The following is a summary of the main results obtained after creating the Matrix of Qualitative Data analysis.

\section{6) Individual characteristics}

a) Perception of the organization's mission

Sense of belonging, trust in the LU and its performance, unawareness of the LU strategy, unawareness of the LU mission and vision, absence of clear planning at all levels and poor human resources management are themes extracted from semi-structured interviews and linked to the perception of the organization's mission. When conducting semi-structured interviews, we asked some questions related to the mission of the Lebanese University.

Generally, employees reported that they were unaware of the organization's mission. This situation leads to frustration and disinterestedness in the work of the organization and its outcomes. Moreover, employees expressed dissatisfaction with human resource management practices leading to lack of trust in the organization's performance. They stated that initiatives indeed exist, yet they are not followed up with plans that produce expected results.

\section{b) Perception of role ambiguity}

Huge workload, slow response in adopting solutions, sense of belonging, task distribution, absence of performance evaluation, managers' poor knowledge of information systems and new technologies, work motivation are themes extracted from semi-structured interviews are linked to the perception of role ambiguity. in this group of themes, most of the findings were related to role ambiguity. Some themes might be connected to other constructs. Role 
ambiguity is an idea that finds its way into previous studies (Pandey \& Wright, 2006; Caillier, 2010; McNabb \& Sepic, 1995). However, role ambiguity is most likely to occur when members of the organization report that they do not receive clear instructions from their supervisors. Moreover, some interviewees reported that many departments do not coordinate their work with each other, leading to unnecessary duplication. These duplications decrease performance and increase the time needed to deal with these duplications. In addition, this type of duplication is somewhat caused by role conflict.

\section{c) Organizational commitment}

Sense of belonging, appreciation, relationship with colleagues, organization of resources allocation, financial rewards are themes extracted from semi-structured interviews that are linked to the perception of organizational commitment. One of the best-known definitions of organizational commitment is the one that distinguishes between commitment-related behaviors and attitudinal commitment. Such behaviors could manifest in someone by being bound to his actions and linked directly or indirectly to the organization. However, attitudinal commitment represents a state in which an individual identifies with a particular organization and its goals and wishes to maintain membership in order to facilitate these goals (Meyer \& Allen, 1991). Thus, based on this definition and other interpretations of organizational commitment we do believe that organizational commitment is linked to the Individual Characteristics construct.

\section{7) Job Characteristics}

a) Perception of unethical misconduct

Recruitment policies in the LU, Frustration, Decision making process \& participation in decision making, Personal interest, unethical misconduct resulting from regulatory gaps are the themes extracted from semi-structured interviews, which are linked to the perception of unethical misconduct. Gebara, Kibranian, \& Al Kadri (2008) noted that unethical misconduct might take another form when a public official seeks personal or group benefit, regardless of how small or considerable it is, he deliberately sacrifices or ignores public interest.

While conducting semi-structured interviews many employees mentioned that unethical misconduct may take several forms depending on the position of the public employee. The link between unethical misconduct and organizational performance has been empirically tested and observed across cultures and across private and public organizations (Gould \& Amaro-Reyes, 1983; Fisman \& Gatti, 2002; Mauro, 1997).

\section{b) Job satisfaction}

Low motivation, frustration, trust in the LU and its performance, job security, unrecognizing the depth of the problems are themes extracted from semi-structured interviews and are linked to the perception of Job satisfaction. Job satisfaction is best defined as "a concept that represents an emotional orientation toward one's work roles within an organization.” (Bess \& Dee, 2008)

Salary and work conditions, role ambiguity, and role conflict are variables that have a direct effect on job performance. Research shows that role ambiguity has a detrimental effect on job satisfaction and, to a lesser extent, a negative effect on job performance.

Semi-structured interviews revealed that job satisfaction might vary from one employee to another. Many employees reported negative job satisfaction but other employees reported a high degree of satisfaction and expressed a strong sense of belonging to the University.

\section{c) Perceived Fairness}

huge workload, task distribution, appreciation, motivation, absence of performance evaluation, conflict management, improper allocation of financial resources are themes extracted from semi-structured interviews and are linked to the perception of fairness. According to J. Stacy Adams (1965), the extent to which people feel that they are being treated in a fair and equitable manner profoundly affects their motivation. People who perceive unfairness will act to restore their feelings of justice. The restoration process might take several forms such as the reduction of effort. 


\section{8) Work environment}

a) Perception of effective communication

Support of the managers, Relationship with colleagues, lack of knowledge in performance management systems, absence of performance evaluation, lack of coordination, creating branches and faculties in a random way, knowledge sharing, self-expression, integration of employees and managers are themes extracted from semistructured interviews and are linked to the perception of effective communication. Ineffective use of data, misunderstanding or distorting data, poor exchange of information between departments and between individuals and faculties, lack of trust between administrative and staff members - these are all signs that communication is not being effective. Communication is a focal point in the organizational performance literature (Jensen, 2003; Pandey \& Garnett, 2006; O'Reilly \& Karlene , 1977). In addition, many organizational theories have linked effective communication to increased performance in organizations.

\section{b) Perception of accountability}

Slow response in adopting solutions, accountability, improper allocation of financial resources, budgetary cuts, unplanned procurement strategy are themes extracted from semi-structured interviews and are linked to the perception of accountability. Many interviewees reported that some of their colleagues are not held accountable for some of their actions. The perception of accountability has been considered as an important construct to study in the case of public agencies (Alexander, 2000; Cutt \& Murray, 2002)

\section{c) Bureaucracy}

Slow response in adopting solutions, recruitment in the LU, decision-making process \& participation in decision making, absence of performance evaluation, relatively slow and weak technological infrastructure, absence of business process, relatively old and outdated laws and regulations, administrative routine and bureaucracy are themes extracted from semi-structured interviews and are linked to the perception of Bureaucracy. As a bureaucracy, a centralized decision- making process characterizes the Lebanese University. In other words, many transactions are transferred to the central administration. This is very paper-intensive and involves numerous authentication signatures, which -depending on the response time of the employee in charge of the transaction- can delay the decision making process. Many interviewees have freely expressed their thoughts regarding the decision making process in the Lebanese University. The reason we are tackling such a topic is that we found that this fact may influences in one way or another, the performance of employees in the central administration and in faculties across Lebanon.

\section{d) Perception of financial resources allocation}

Personal interest, The LU budget, organization of resource allocation, improper allocation of financial resources, budgetary cuts, unplanned procurement strategy are themes extracted from semi-structured interviews and are linked to the perception of financial resources allocation. Al-Amin et al. (1999) noted that the government provides $95 \%$ of the Lebanese university budget. In fact, the issue of resources can be explained in light of the Resource Dependency theory. The theory suggests "Resource dependence theory is manifested in organizations that see the possibility of effective action vis-à-vis the external environment" (Bess \& Dee, 2008, p. 148). In other words, an organization should know how to obtain resources from its environment e.g. external entities (Salancik \& Pfeffer, 1978). The trend of government spending on education is unpredictable with no clear direction as to whether to increase education budgets exponentially or not (Nahas, 2009). Employees are convinced that the government is unable to ensure proper budgeting strategies. In one interview with a financial officer, he noted and gave us many indicators that the Lebanese university budget is not expanding at the same rate as the needs of the university. There is a convincing perception within the work environment that the Lebanese university is always short on budget. This perception may cause some disquiet on an individual level equal to a certain extent to the turbulence on an organizational level. We noticed that when employees discussed financial matters in the Lebanese university, they expressed disgruntled feelings. They used negative tonality in their voices; they seemed frustrated and unable to do anything about it.

\section{9) External Environment Characteristics}

\section{a) Perception of Political influence}

Conflict management, sectarian influence, political influence, personal interest, power abuse, creating branches and faculties based on sectarian considerations are themes extracted from semi-structured interviews and are linked to the perception of political influence. there is a common belief among the interviewee in the Lebanese University, 
that politics and politicians influence many aspects of the university. Few disagreed with this fact. In addition, many employees, during the semi-structured interviews stated that politics interfere with processes such as the appointment of faculty and administrative members, deans and even contract-based academics and administrators.

b) Public service motivation

Slow response in adopting solutions, Sense of belonging, Absence of clear planning on all levels, not recognizing the depth of the problems, Poor human resources management are themes extracted from semi-structured interviews and are linked to the perception of Public Service Motivation. Public service motivation (PSM) is defined as an individual's predisposition to respond to motives grounded primarily or uniquely in public institutions (Perry J. , 1996). The construct is crucial when researchers intend to measure the performance of public agencies (Kim S. , 2008; Perry J. , 1997).

After summarizing the findings according to the relevance to construct extracted from the literature review, we draw a relationship model that depicts the relationship between these variables extracted from the semi-structured interviews and linked to the corresponding literature. This causal scheme will be tested using Structural Equation Modeling Algorithms (SEM) using the Smart PLS software. However, the present study will only show these relationships. The statistical tests and the related structural equations will be reported in another study detailing the steps and the findings of the quantitative study.

\section{c) The causal scheme}

The casual scheme in Figure (4) is primarily based on Perry \& Porter (1982) framework that was created to test the motivational basis of public employees. We adopted it, and considered the four essential antecedents affecting the performance of public employees. This framework is aligned with Steers (1977) framework. The four antecedents are Individual Characteristics (IC), External Environment Characteristics (EEC), Work Environment Characteristics (WEC), Job Characteristics (JC) and Perceived Organizational Performance (POP).

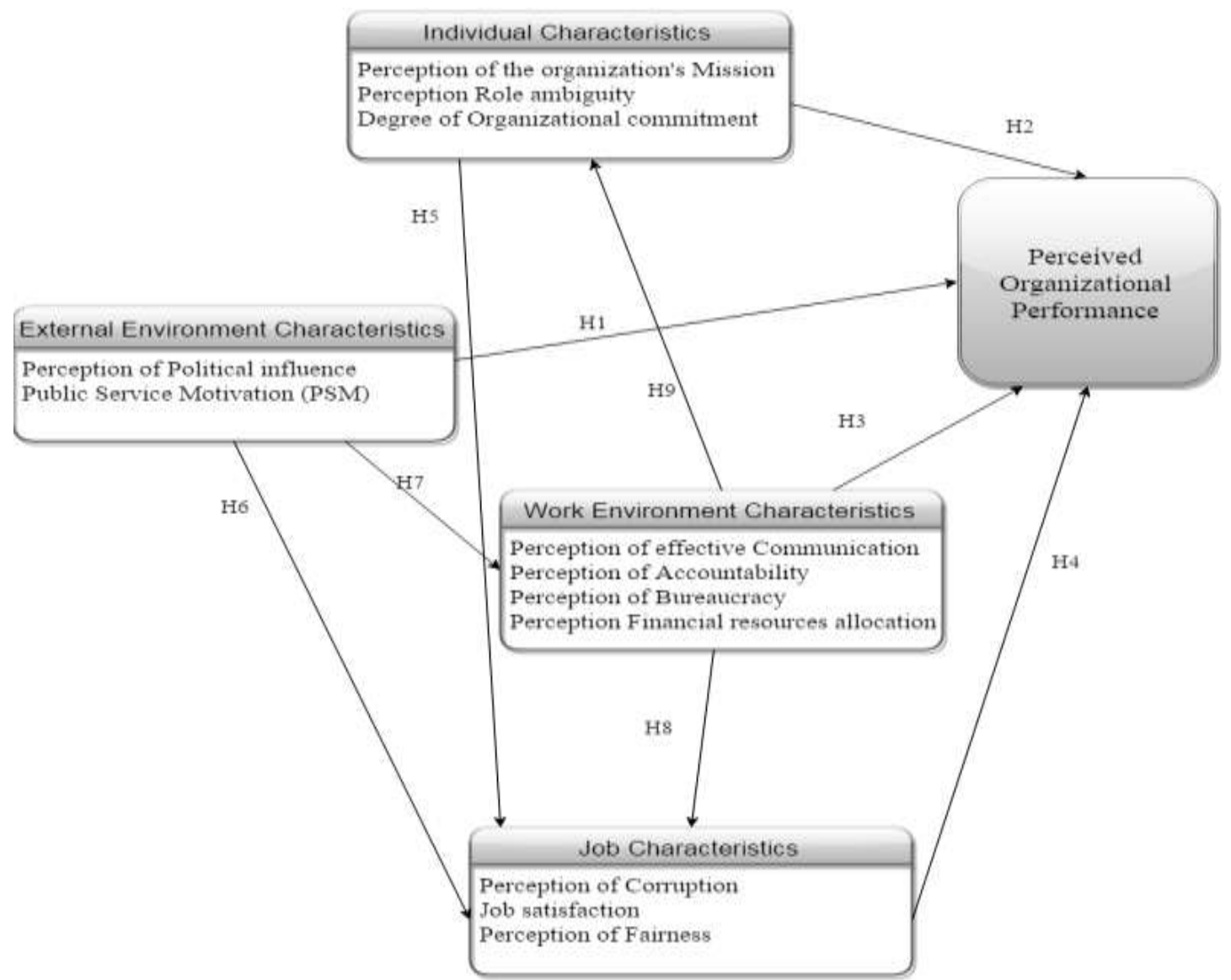

Figure 4:- The causal scheme depicting the relationship between the variables extracted from the qualitative study 


\section{Discussion and recommendations:-}

In this research, we applied theoretical concepts in the organizational performance literature in the context of a Lebanese public higher education institution. The suggested model has been empirically tested and validated according to the principles and methods of other studies performed in different organizational contexts.

The research model predicts two main constructs in the Organizational Performance literature, the Perception of Organizational Performance, and Job Characteristics. These two constructs have an impact on employees' attitudes (Mowday, Steers, \& Porter, 1979; Parker, et al., 2003; Perry \& Porter, 1982).

Based on intensive review of the literature, we assumed that if we could implement a tool that could measure and manage the dimensions of organizational performance in the Lebanese University, then decision-makers could enhance the administrative and academic performance of the one and only public higher education institution in Lebanon. Since the Lebanese University does not have a Balanced Scorecard framework, nor it has a performanceoriented framework, there was a need to study the possible factors that might have an impact on implementing new Management Control Tools. However, implementing Management Control Tools is a change, and employees tend to be reluctant to accept change. A change process requires that all level of the organization embrace it. Many studies investigated how to drive change in various organizations. These researchers found that there is a relationship between employees' attitude and change. Thus, they investigated latent variables e.g. Job characteristics, Work Environment Characteristics, External Environment Characteristics and Individual Characteristics, which could be antecedents of a change in attitude and consequently to change behavior.

Studying human behavior required a complementary set of psychological theories. They concluded that psychological factors could be the reason behind accepting something new in the organization.

Therefore, many models were created to measure and to predict human intention vis-à-vis a given behavior. Examples of behavior could be using information technology and MCT or predicting the entrepreneurial intention of newly graduated students or more simply predicting the likelihood of using a type of medicine. These models were subject to replications either in different context or to extension in different contexts.

Our model constituted a replication of past studies, with an adaptation to public higher education institution in Lebanon. The causal scheme in our study is the results of in depth observation and semi-structured interviews. The relationships found are of a great importance to the decision makers in the Lebanese University. The model Allow for decision makers to draw more attention to the Public higher education in Lebanon. It also allows them to have more contextual interventions, which will might lead to more performance-oriented decisions. The results of the quantitative study will be reported in a second study. The current study allows to draw some managerial recommendations for decision makers. The following is a list of these recommendations.

\section{0) Recommendations}

Our findings depict some important relationships that have a positive or negative impact on the perceived organizational performance construct, therefore, we list some of the recommendations that might be implemented to attenuate the negative effect and to optimize the positive impact of the relationships.

1- Increasing the financial and managerial independence of the Lebanese University by increasing the participation of experts and academics in reshaping the administrative, financial, technological, and academic situation.

2- Updating current financial and administrative laws and regulations to ban unethical practices and to increase accountability.

3- Creating a better rewards allocation strategy to ensure fairness among employees.

4- Setting up a goal-oriented framework that enables clearer accountability and task allocation. In addition to the elaboration of a performance management culture that emphasizes results and achievements, by using performance appraisals, key performance indicators and applying the concept of the Balanced Scorecard.

5- Aligning the interests of policy makers and employees with the strategy and goals of the Lebanese University.

6- Allowing employees to participate in adopting the Information System. In this way, the Lebanese University will definitely decrease the cost of not using the system.

7- Recognizing that some political activities maybe essential to the functioning of work groups. Yet, their political activities may have unanticipated consequences on the individual level. If the actions are perceived as political (i.e. based on favoritism and on self-interest) then they may have far-reaching effects on members of the organization. 
8- In order to respond to perception of organizational politics, decision makers (e.g. president, deans, directors, head of departments etc.) in the Lebanese University must deal with the social context in which they are working, by creating a teamwork atmosphere and by making team members satisfied in their work place. Therefore, the human resource departments actively create competency models that incorporate the goal of discouraging political activities and providing incentives for directors to suitable create work environments.

9- Training employees in effective conflict resolution, time management skills, information system usage, financial and budgeting techniques, implementing, and using management control tools etc.

10- Working with employees to increase their awareness of their duties and responsibilities to increase their Public service motivation.

\section{Conclusion:-}

Change in the Lebanese University could not be achieved without the efforts of the Government from one hand and public employees and academics from the other hand. This balance in distributing responsibilities will always be the driver of success in public organizations as well as in private organizations. We cannot only blame the government without checking whether employees are competent. It is importance to balance the distribution of responsibilities (power and participation) among managers and employees. When balance is achieved, performance outcomes are more likely to float on the surface. In the Lebanese University, change will be more likely to occur when the Government and employees have good intentions to adopt change. If they do so, they will achieve Organizational Performance, and they will produce high quality educational services to the Lebanese students. As a result, they will enhance the outcomes of the public Higher Education Institutions.

\section{References:-}

1. Adams, J. (1965). Inequity in social exchange. Advances in experimental social psychology, 2, $267-299$.

2. Adler, P., \& Adler, P. (1987). Membership roles in field research. Sage.

3. Ajzen, I. (1991). The theory of planned behavior. Organizational Behavior and Human Decision Processes, 50, 179-211.

4. Ajzen, I., \& Flood, M. (2009). From intentions to behavior : implementation intention, commitment, and conscientiousness. Journal of applied social psychology, 39, 1356-1372.

5. Al-Amin, A. e. (1999). قضايا الجامعة اللبنانية وإصلاحها Beirut: Dar El-Nahar.

6. Alexander, F. (2000). The changing face of accountability: Monitoring and assessing institutional performance in higher education. Journal of Higher Education , 411-431.

7. Andreassen, T. (1994). Satisfaction, loyalty and reputation as indicators of customer orientation in the public sector. International Journal of Public Sector management, 7(2), 16-34.

8. Bartunek, J., \& Franzak, F. (1988). The effects of organizational restructuring on frames of reference and cooperation. Journal of Management, 14(4), 579-592.

9. Bess, J., \& Dee, J. (2008). Understanding college and university organization: Theories for Effective Policy and Practice. (Vol. Two Volume Set). Stylus Publishing, LLC.

10. Black, S., Briggs, S., \& Keogh, W. (2001). Service quality performance measurement in public/private sectors. Managerial Auditing Journal, 16(7), 400-405.

11. Brewer, G., \& Selden, S. (2000). Why elephants gallop: Assessing and predicting organizational performance in federal agencies. Journal of public administration research and theory, 10(4), 685-712.

12. Caillier, J. (2010). Factors affecting job performance in public agencies. Public Performance \& Management Review, 34(2), 139-165.

13. Cutt, J., \& Murray, V. (2002). Accountability and effectiveness evaluation in non-profit organizations. London and New York: Routledge.

14. Davis, F., Bagozzi, R., \& Warshaw, P. (1992). Extrinsic and intrinsic motivation to use computers in the workplace. Journal of applied social psychology, 22(14), 1111-1132.

15. Deem, R., Hillyard, S., \& Reed, M. (2007). Knowledge, higher education, and the new managerialism: The changing management of UK universities. Oxford University Press.

16. Evrard, Y., Pras, B., \& Roux, E. (1997). Market: études et recherches en Marketing, . Dunod.

17. Fern, E. (1982). Use of focus groups for idea generation: the effects of group size, acquaintanceship, and moderator on response quantity and quality. Journal of marketing Research, 1(13).

18. Fisman, R., \& Gatti, R. (2002). Decentralization and corruption: evidence across countries. Journal of Public Economics, 83(3), 325-345. 
19. Gebara, K., Kibranian, G., \& Al Kadri, M. (2008). Towards a national Anti-Corruption Strategy. Beirut: The Lebanese Transparency Association.

20. Gould, D., \& Amaro-Reyes, J. (1983, december 1). The effects of corruption on administrative performance. World Bank Staff Working Paper, p. 580.

21. Harb, B. (2011). Les sources d'implication des gestionnaires publics au travail: Cas de la fonction publique au Liban. (Doctoral dissertation, Université Paris-Dauphine).

22. Jensen, M. (2003). Organizational communication: A review. Norway: R\&D Report 1.

23. Kim, S. (2008). Revising Perry's measurement scale of public service motivation. The American Review of Public Administration., 149-164.

24. Mauro, P. (1997). The effects of corruption on growth, investment, and government expenditure: a crosscountry analysis. Corruption and the global economy, 83.

25. McNabb, D., \& Sepic, F. (1995). Culture, climate, and total quality management: Measuring readiness for change. Public Productivity \& Management Review, 369-385.

26. Meyer, J., \& Allen, N. (1991). A three-component conceptualization of organizational commitment. Human resource management review, 1(1), 61-89.

27. Mowday, R., Steers, R., \& Porter, L. (1979). The measurement of organizational commitment. Journal of vocational behavior, 14(2), 224-247.

28. Nahas, C. (2009). Financing and political economy of higher education in Lebanon. Lebanon: Economic Research Forum.

29. OECD. (2008). Enseignement supérieur pour la société de la connaissance. Examen thématique de l'OCDE sur l'enseignement supérieur : Rapport de synthèse. OECD.

30. O'Reilly, C., \& Karlene , H. (1977). Communication and Performance in Organizations. Academy of Management Proceedings., 1, 375-379.

31. Pandey, S., \& Garnett, J. (2006). Exploring public sector communication performance: Testing a model and drawing implications. ublic Administration Review, 66(1), 37-51.

32. Pandey, S., \& Wright, B. (2006). Connecting the dots in public management: Political environment, organizational goal ambiguity, and the public manager's role ambiguity. Journal of Public Administration Research and Theory, 16(4), 511-532.

33. Parker, C., Baltes, B., Young, S., Huff, J., Altmann, R., Lacost, H., et al. (2003). Relationships between psychological climate perceptions and work outcomes: a meta-analytic review. Journal of Organizational Behavior, 24(4), 389-416.

34. Perry, J. (1996). Measuring public service motivation: An assessment of construct reliability and validity. ournal of public administration research and theory, 6(1), 5-22.

35. Perry, J. (1997). Antecedents of public service motivation. Journal of public administration research and theory, 7(2), 181-197.

36. Perry, J., \& Porter, L. (1982). Factors Affecting the Context for Motivation in Public Organizations. Academy of Management Review, 7(1), 89-98.

37. Quivy, R., \& Campendhout, L. (1995). Manual de recherches en sicences sociales. Paris: Dunod.

38. Ring, P., \& Perry, J. (1985). Strategic management in public and private organizations: implications of distinctive contexts and constraints. Academy of Management Journal, 10(7), 276-286.

39. Salancik, G., \& Pfeffer, J. (1978). A social information processing approach to job attitudes and task design. Administrative science quarterly, 224-253.

40. Simon, H. (1957). Administrative Behaviour (2 ed.). New York: Free press.

41. Steers, R. (1977). Antecedents and outcomes of organizational commitment. Administrative science quarterly, 46-56.

42. Thietart, R. (1999). Méthodes de recherche en management. Paris: Dunod.

43. UNDP. (2014). Arab Knowledge Report 2014 Youth and Localisation of Knowledge=Summaries=. Dubai: United Nations Development Programme (UNDP).

44. Venkatesh, V., \& Morris, M. (2000). Why don't men ever stop to ask for directions? Gender, social influence, and their role in technology acceptance and usage behavior. MIS quarterly, 24(1), 115-139. 


\section{Appendices}

Appendix A

Interview guide

Mission vision and strategies

1. Would you say that employees in your faculties are familiar with the institution's mission and vision?

2. What are the disablers that prevent the communication of strategy and objectives?

- What can be done to overcome them?

3. Do you think that time; energy and resources are well used to accomplish the institution's strategy?

4. What objectives do the institution has, and what strategies are set to achieve these goals and where do you fit in?

\section{Communication channels between hierarchical positions}

5. How can you describe the communication channels between the various hierarchical levels in the institution?

6. What can you say about your relationship with higher or lower hierarchical levels?

- How do you use these relationships to improve the institution performance?

Decision making and communication), and evolution perspectives

7. Are you familiar with any management control tools that could trace the progress of the institution's strategy?

$\circ$ Do you think that the Lebanese university is ready to implement management control tool (balanced scorecard)? Why?

8. How frequently does the Lebanese university staff (faculty staff) carry out training on new skills and knowledge?

$\circ \quad$ What type of training do you think should be given?

9. Where do you see the Lebanese University in 10 years' time?

\section{Administrative situation in the Lebanese University}

1. What do you think is the purpose of management at the level of Dean/Head of School?

2. In relation to your faculty/school, do you consider yourself to be a leader, resource handler, representative academic or hands on head of a unit, or are you all those things?

3. How does your work within the university contribute to or relate to change and development within the institution?

$\circ$ What is your perception to the term organizational change?

4. How do you manage your daily tasks?

$\circ$ Who sets your tasks?

- And who monitors your progression?

- What do you do if you are assigned a task that you do not wish to handle?

5. What kind of struggles do you face in the faculty?

$\circ \quad$ What kind of effect do they have?

- And what can you do to mitigate their influence?

6. What can you tell us about the conventions in your workplace?

- Do you think these conventions are enablers to a well-managed institution?

7. How can you illustrate the relation between academics and non-academics?

Technical situation LU

1. What are the main resources you have that enable you to manage?

a. What are the tools with which you can have control or influence?

b. What would improve your ability to manage?

2. Why do you think the LU is still behind the technological evolution on both administrative and academic level compared with its peers?

3. What human factors do you think are the most influential on the adoption of new technologies?

4. What can you say about the technological resources in your faculties?

a. Are they enough to enable the technical staff to design a well-designed information system strategy? (whether in faculties or in the central administration)

\section{Bureaucratic and financial situation}

1. How can you describe the bureaucracy in the LU?

2. In your own words, what can we do to mitigate its influence on the administrative performance?

3. Have you encountered any situation where certain employees have benefited in one way or another from bureaucracy? 
4. How can bureaucracy influence financial performance of the LU?

5. What can you say about the use of financial resources of the LU?

6. What could be done to improve the financial performance in the LU?

7. Do you know any management control tool to be used to measure the financial performance?

a. How can we implement new management control tools along with the existence of bureaucracy?

\section{Power perception and political influence}

1. How do political parties influence the administrative and academic situation in the LU? And other stakeholders (students)?

2. Have you encountered any situation where an external party exerted any kind of influence on the Lebanese university?

a. Why do you think caused this influence?

What do you think are the benefits or advantages of such influence?

\section{Appendices B: Matrix of qualitative Data Analysis}

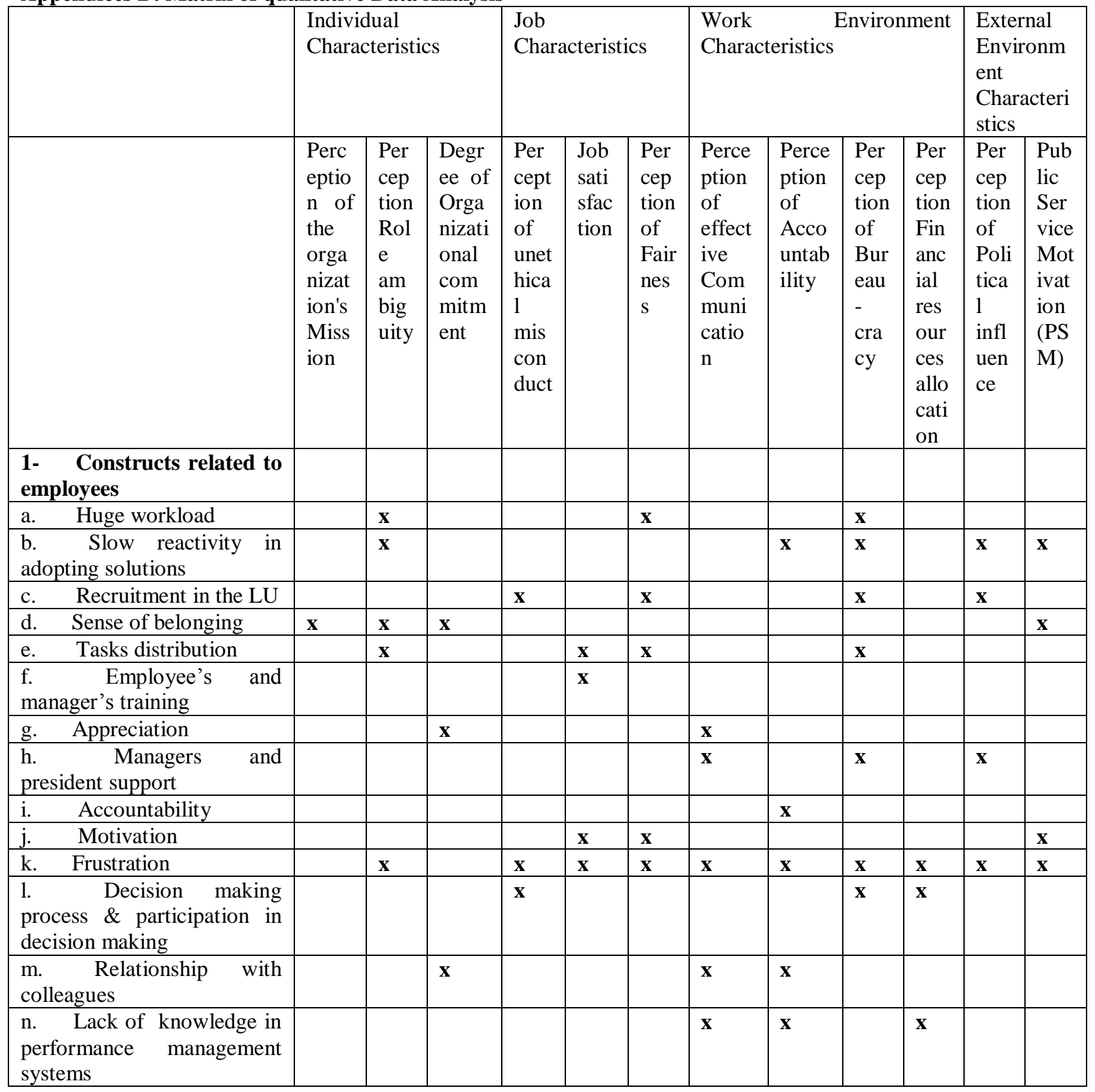




\begin{tabular}{|c|c|c|c|c|c|c|c|c|c|c|c|c|}
\hline $\begin{array}{l}\text { o. Trust in the LU and its } \\
\text { performance }\end{array}$ & $\mathbf{x}$ & & $\mathbf{x}$ & $\mathbf{x}$ & & & & & & & $\mathbf{x}$ & $\mathbf{x}$ \\
\hline $\begin{array}{lcc}\text { p. Absence } & \text { of } \\
\text { performance evaluation } & \\
\end{array}$ & & $\mathbf{x}$ & & & & $\mathbf{x}$ & $\mathbf{x}$ & & $\mathbf{x}$ & $\mathbf{x}$ & & \\
\hline q. Job security & & & & & $\mathbf{x}$ & $\mathbf{x}$ & & & & $\mathbf{x}$ & $\mathbf{x}$ & $\mathbf{x}$ \\
\hline \multicolumn{13}{|l|}{$\begin{array}{ll}\text { r. Job affective } \\
\text { attachment }\end{array}$} \\
\hline $\begin{array}{ll}\text { s. } & \text { Personal interest } \\
\end{array}$ & & & & $\mathbf{x}$ & & $\mathbf{x}$ & & & & $\mathbf{x}$ & $\mathbf{x}$ & \\
\hline t. Lack of coordination & & & & & & & $\mathbf{x}$ & & $\mathbf{x}$ & & & \\
\hline u. $\quad$ Conflict management & & $\mathbf{x}$ & & & & $\mathbf{x}$ & $\mathbf{x}$ & $\mathbf{x}$ & & & $\mathbf{x}$ & \\
\hline 2- $\quad$ Political influence: & & & & & & & & & & & & \\
\hline a. Sectarian influence & & & & & & & & & & & $\mathbf{x}$ & \\
\hline b. $\quad$ Political influence & & & & & & & & & & & $\mathbf{x}$ & \\
\hline Personal interest & & & & $\mathbf{x}$ & & $\mathbf{x}$ & & & & $\mathbf{x}$ & $\mathbf{x}$ & \\
\hline d. $\quad$ Power abuse & & & & $\mathbf{x}$ & & & & & & & $\mathbf{x}$ & \\
\hline 3- $\quad$ Resources allocation & & & & & & & & & & & & \\
\hline a. $\quad$ The LU budget & & & & & & & & & & $\mathbf{x}$ & & \\
\hline $\begin{array}{lll}\text { b. } & \text { Organization of } \\
\text { resources allocation } & \end{array}$ & & & $\mathbf{x}$ & $\mathbf{x}$ & & $\mathbf{x}$ & & $\mathbf{x}$ & & $\mathbf{x}$ & & \\
\hline c. $\quad$ Financial rewards & & & $\mathbf{x}$ & $\mathbf{x}$ & & $\mathbf{x}$ & & $\mathbf{x}$ & & $\mathbf{x}$ & & \\
\hline $\begin{array}{l}\text { d. Improper allocation of } \\
\text { financial resources }\end{array}$ & & & $\mathbf{x}$ & $\mathbf{x}$ & & $\mathbf{x}$ & & $\mathbf{x}$ & & $\mathbf{x}$ & & \\
\hline e. $\quad$ Budgetary cuts & & & & & & & & $\mathbf{x}$ & & $\mathbf{x}$ & & \\
\hline $\begin{array}{lll}\text { f. } & \text { Unrealistic monthly } \\
\text { salary } & & \\
\end{array}$ & & & & & & $\mathbf{x}$ & & & & & & \\
\hline $\begin{array}{l}\text { g. Unplanned } \\
\text { procurement strategy }\end{array}$ & & & & $\mathbf{x}$ & & & & $\mathbf{x}$ & & $\mathbf{x}$ & & \\
\hline \multicolumn{13}{|l|}{ 4- $\quad$ Technological aspect: } \\
\hline $\begin{array}{lll}\text { a. } & \text { Information } & \text { system } \\
\text { usage } & & \\
\end{array}$ & & & & & $\mathbf{x}$ & & $\mathbf{x}$ & & $\mathbf{x}$ & $\mathbf{x}$ & & $\mathbf{x}$ \\
\hline $\begin{array}{l}\text { b. Mandatory use of } \\
\text { information systems }\end{array}$ & & & & & $\mathbf{x}$ & & $\mathbf{x}$ & & $\mathbf{x}$ & $\mathbf{x}$ & & $\mathbf{x}$ \\
\hline c. Late use of technology & & & & & $\mathbf{x}$ & & $\mathbf{x}$ & & $\mathbf{x}$ & $\mathbf{x}$ & & $\mathbf{x}$ \\
\hline $\begin{array}{l}\text { d. Managers' low } \\
\text { knowledge in information } \\
\text { system and new } \\
\text { technologies }\end{array}$ & & $\mathbf{x}$ & & & $\mathbf{x}$ & & $\mathbf{x}$ & & $\mathbf{x}$ & & & \\
\hline $\begin{array}{l}\text { e. Relatively slow and } \\
\text { weak } \\
\text { infrastructure. }\end{array}$ & & & & & & & & & $\mathbf{x}$ & $\mathbf{x}$ & & \\
\hline 5- $\quad$ Geographical aspects & & & & & & & & & & & & \\
\hline $\begin{array}{l}\text { a. Creating branches and } \\
\text { faculties in a random way }\end{array}$ & & & & & & & $\mathbf{x}$ & & & $\mathbf{x}$ & $\mathbf{x}$ & \\
\hline \multicolumn{13}{|l|}{$\begin{array}{l}\text { 6- LU strategy and } \\
\text { mission }\end{array}$} \\
\hline $\begin{array}{l}\text { a. Absence of business } \\
\text { process }\end{array}$ & & $\mathbf{x}$ & & & & & & & $\mathbf{x}$ & & & \\
\hline $\begin{array}{l}\text { b. Ignorance of the LU } \\
\text { strategy }\end{array}$ & $\mathbf{x}$ & & & & & & & & & & & \\
\hline $\begin{array}{l}\text { c. Ignorance in the LU } \\
\text { mission and vision }\end{array}$ & $\mathbf{x}$ & & & & & & & & & & & \\
\hline d. $\quad$ Future of the LU & & & & & & & & & & & & $\mathbf{x}$ \\
\hline $\begin{array}{l}\text { e. Absence of clear } \\
\text { planning on all levels }\end{array}$ & $\mathbf{x}$ & $\mathbf{x}$ & $\mathbf{x}$ & & $\mathbf{x}$ & & $\mathbf{x}$ & & $\mathbf{x}$ & & & $\mathbf{x}$ \\
\hline
\end{tabular}




\begin{tabular}{|c|c|c|c|c|c|c|c|c|c|c|c|c|}
\hline $\begin{array}{l}7-\text { LU laws and state } \\
\text { regulations }\end{array}$ & & & & & & & & & & & & \\
\hline $\begin{array}{llll}\text { a. Relatively old } & \text { and } \\
\text { outdated laws } & & \text { and } \\
\text { regulations } & & & \\
\end{array}$ & & $\mathbf{x}$ & & & & & & & $\mathbf{x}$ & & & \\
\hline $\begin{array}{l}\text { b. Unethical misconduct } \\
\text { resulting for regulatory gaps }\end{array}$ & & & & $\mathbf{x}$ & & & & & & & & \\
\hline $\begin{array}{l}\text { c. Administrative routine } \\
\text { and bureaucracy }\end{array}$ & & & & & & & & & $\mathbf{x}$ & & & \\
\hline $\begin{array}{l}\text { d. LU independence on } \\
\text { various aspects }\end{array}$ & & & & & & & & & & & $\mathbf{x}$ & \\
\hline $\begin{array}{l}\text { e. Laws renewal and } \\
\text { update }\end{array}$ & & & & & & & & & $\mathbf{x}$ & & & \\
\hline $\begin{array}{ll}8- & \text { Continued } \\
\text { employee level } & \end{array}$ & & & & & & & & & & & & \\
\hline $\begin{array}{l}\text { a. Demographic traits of } \\
\text { employees }\end{array}$ & & & & & & & & & & & & \\
\hline $\begin{array}{l}\text { b. Unrecognizing the } \\
\text { depth of the problems }\end{array}$ & & $\mathbf{x}$ & & & & & & & $\mathbf{x}$ & & & $\mathbf{x}$ \\
\hline c. Knowledge sharing & & & & & & & $\mathbf{x}$ & $\mathbf{x}$ & & & & \\
\hline $\begin{array}{ll}\text { d. } & \text { Self-expression }\end{array}$ & & & & & $\mathbf{x}$ & & $\mathbf{x}$ & & & & & \\
\hline $\begin{array}{l}\text { e. Bad human resources } \\
\text { management }\end{array}$ & $\mathbf{x}$ & $\mathbf{x}$ & $\mathbf{x}$ & & $\mathbf{x}$ & $\mathbf{x}$ & & & & & & $\mathbf{x}$ \\
\hline $\begin{array}{l}\text { f. Feeling of insecurity } \\
\text { in the work }\end{array}$ & & & & & $\mathbf{x}$ & & & & & & & \\
\hline $\begin{array}{ll}\text { g. Fairness between } \\
\text { employees }\end{array}$ & & & & & & $\mathbf{x}$ & & & & & & \\
\hline h. Intention to work & & $\mathbf{x}$ & $\mathbf{x}$ & & $\mathbf{x}$ & & & & & & & \\
\hline i. $\quad$ Work ethics & & $\mathbf{x}$ & $\mathbf{x}$ & & $\mathbf{x}$ & & & & & & & \\
\hline $\begin{array}{ll}\mathrm{j} . & \text { Integration } \\
\text { employees and managers }\end{array}$ & & & & $\mathbf{x}$ & & & $\mathbf{x}$ & & & & & \\
\hline k. Unethical misconduct & & & & $\mathbf{x}$ & & & & & & & & \\
\hline Total & 6 & 15 & 11 & 14 & 15 & 16 & 17 & 12 & 20 & 18 & 14 & 13 \\
\hline
\end{tabular}


Appendix C:- Quantification of the semi-structured interviews results Based on the Matrix of qualitative Data Analysis
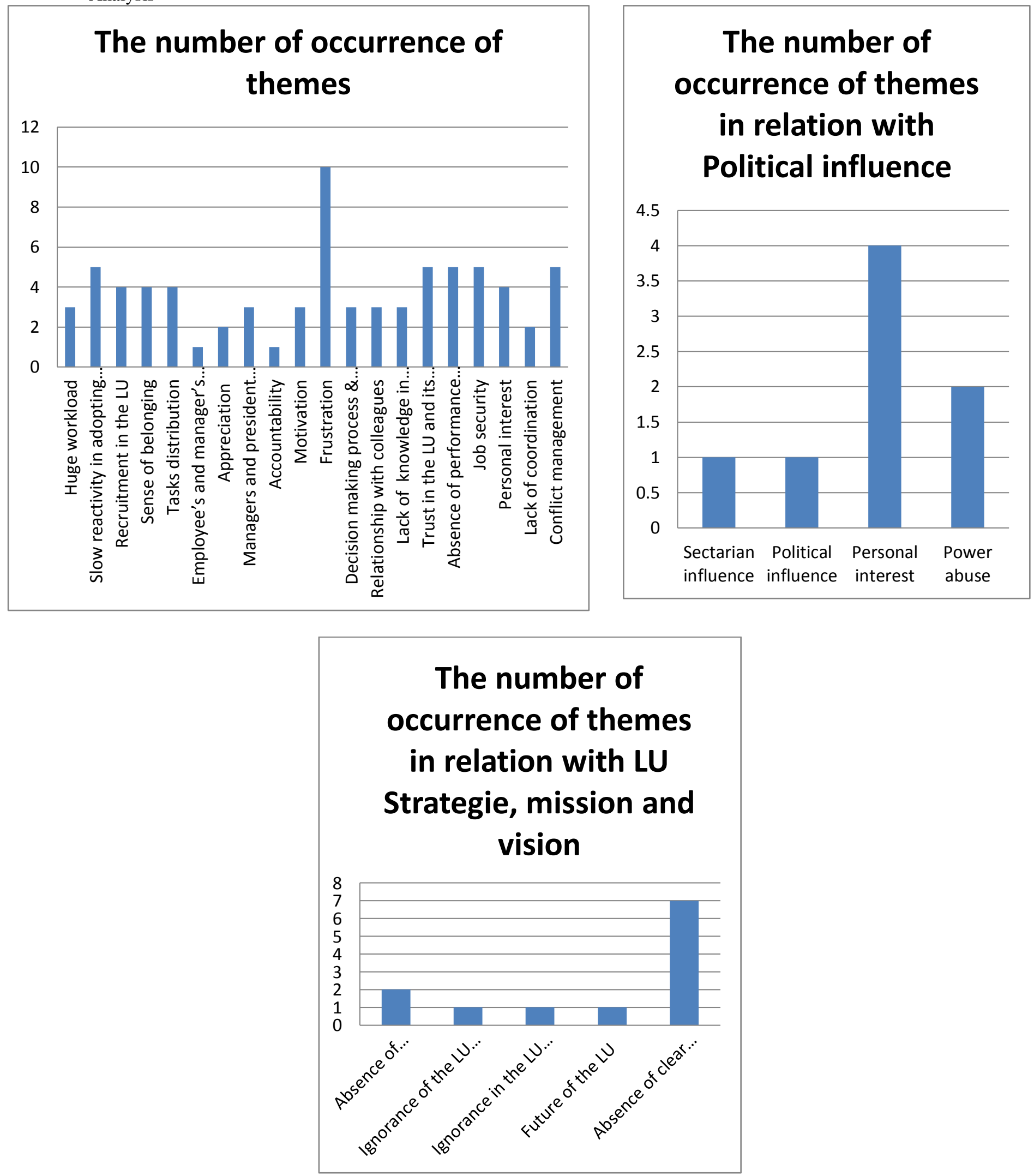

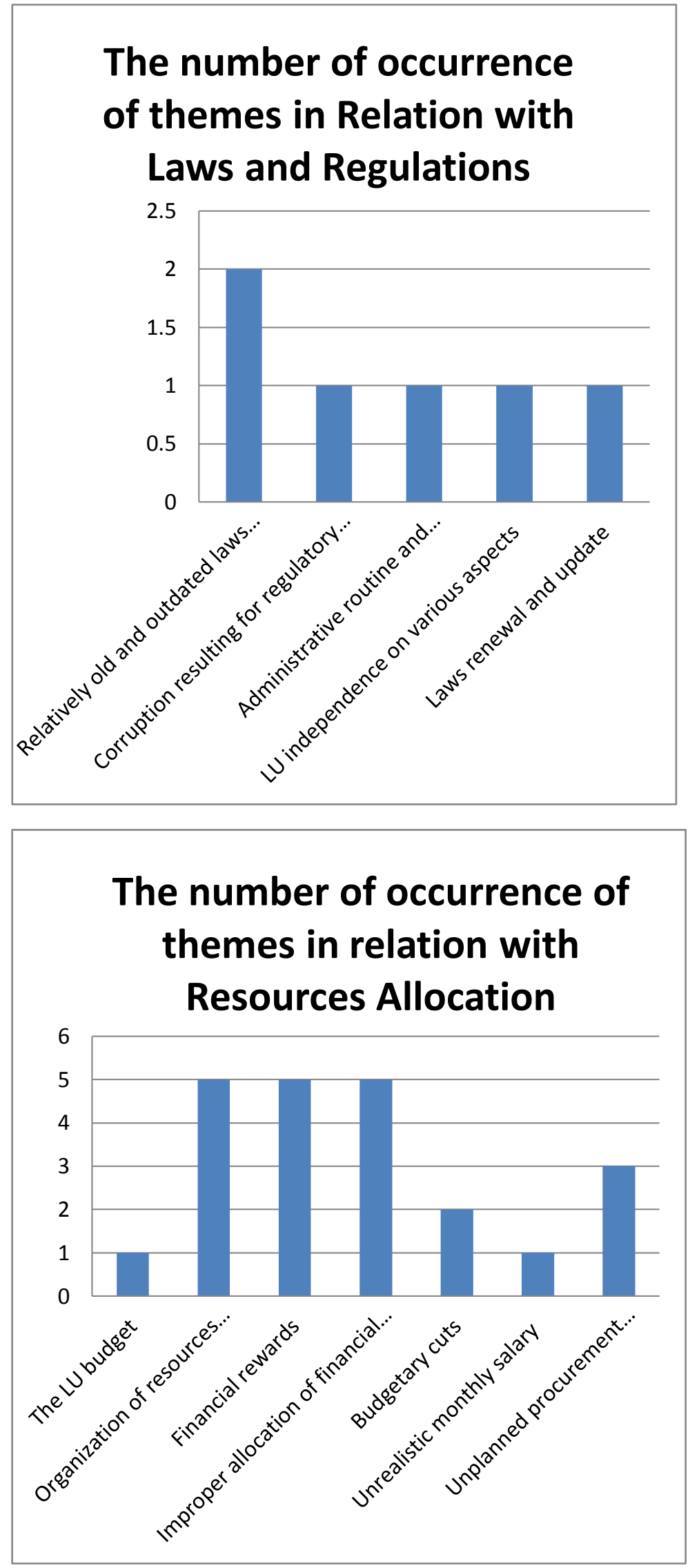


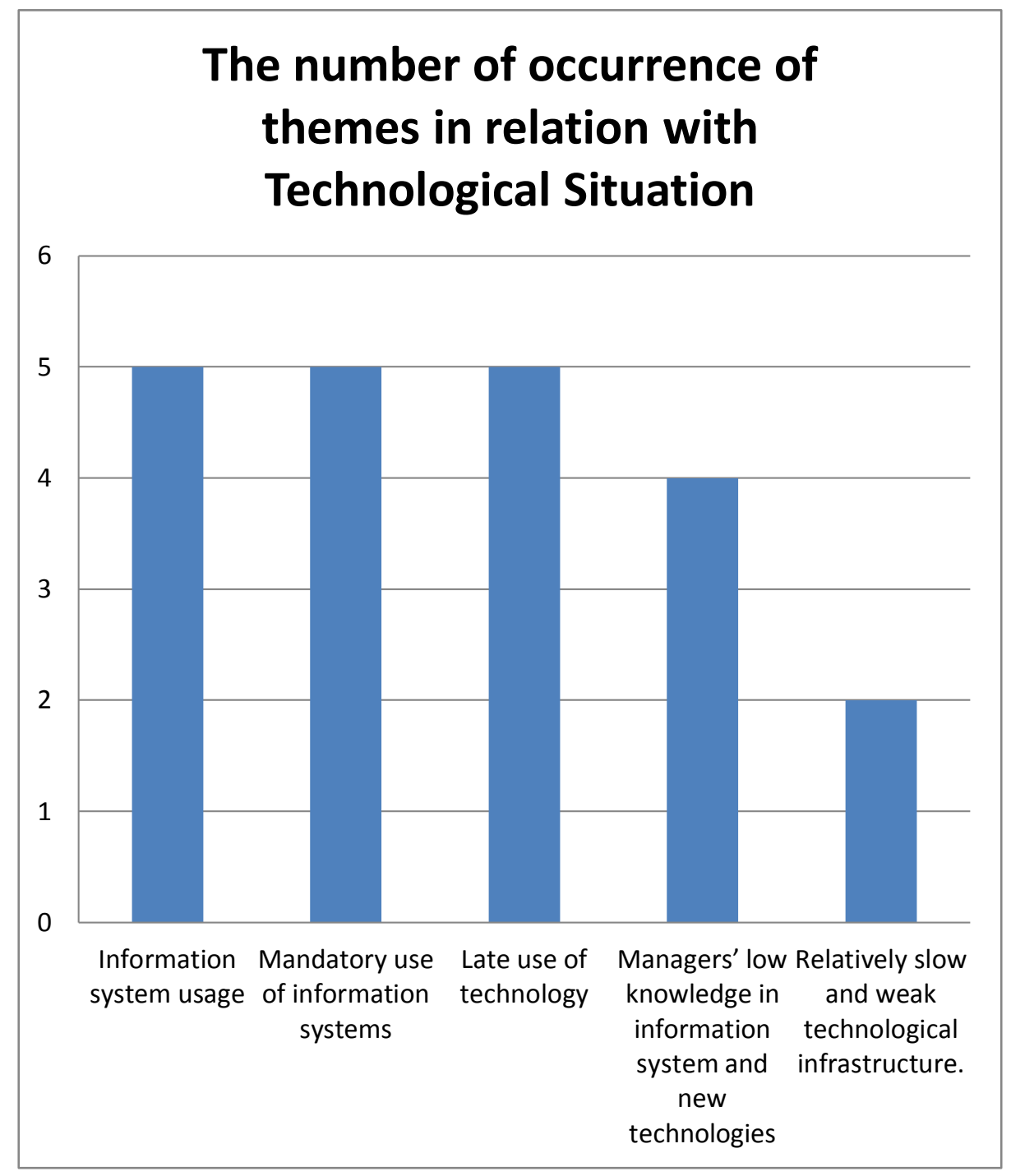



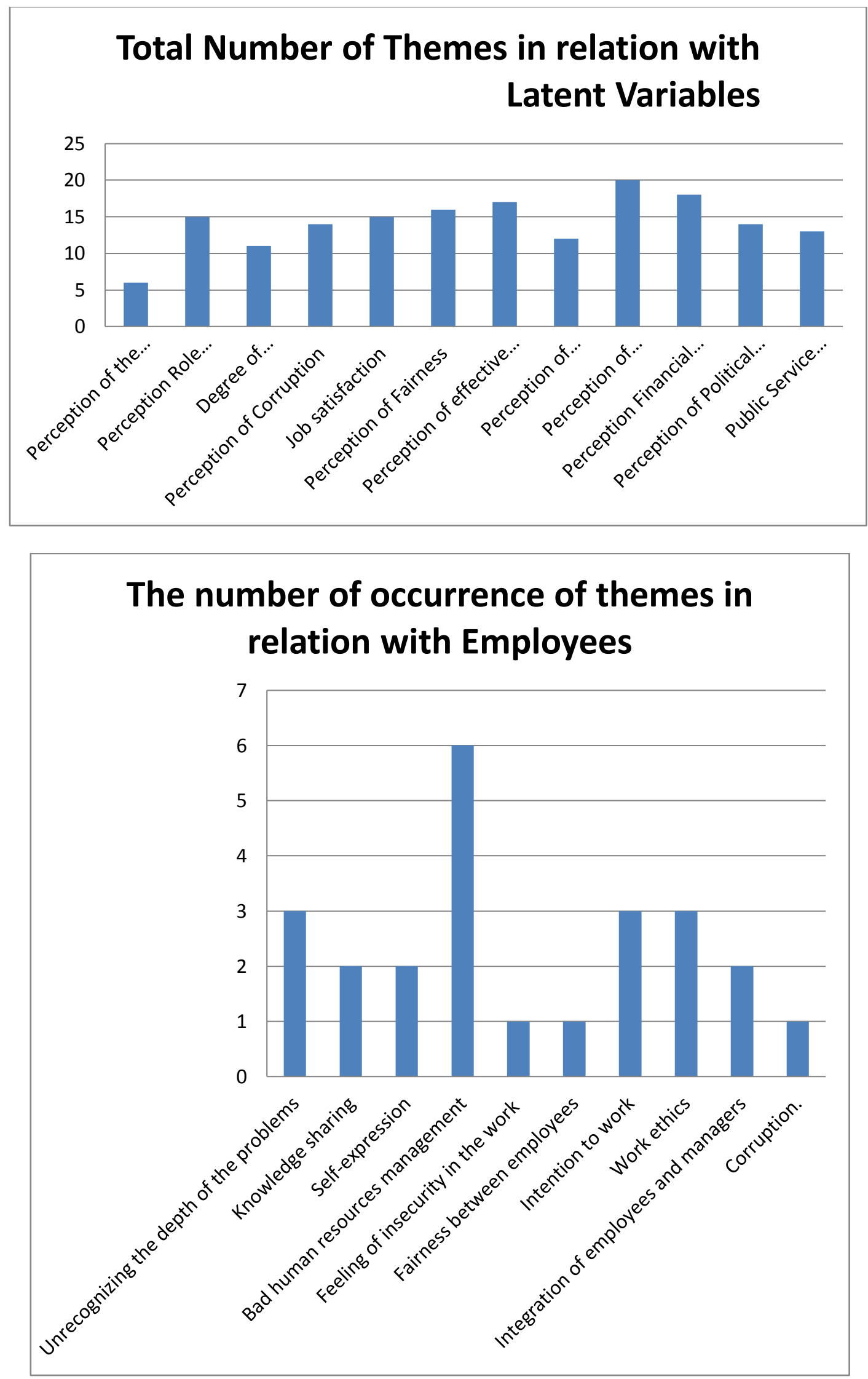